J. Reprod. Fert. (1967) 13, 149-154

\title{
STUDIES ON THE SPECIFICITY OF THE ASSAY METHOD FOR THE GONADOTROPHIN INHIBITING FACTOR
}

\author{
MARIAM KRISHNAMURTI AND E. T. BELL \\ Medical Research Council, Clinical Endocrinology Research Unit, \\ University of Edinburgh
}

(Received 19th May 1966)

\begin{abstract}
Summary. The specificity of the assay method for the gonadotrophin inhibiting factor (GIF) has been studied in two ways. In the first part of the study the biological activity of various gonadotrophin preparations remaining after heating at $100^{\circ} \mathrm{C}$ for $1 \mathrm{hr}$ was measured. In the second part the effect of these hormones on the bio-assay method for the GIF was investigated.

Following heating it has been shown that most, but not all, of the biological activity of the preparations studied is destroyed when assayed by specific methods. Gonadotrophins derived from ovine pituitary tissue, but not from human urine, have been demonstrated to be capable of causing a uterine response in the assay for the GIF.

It is concluded that the assay method for the GIF is not specific. For this reason care must be taken in interpreting the results of assays of the GIF in clinical situations in which high endogenous gonadotrophin levels are likely to be present.
\end{abstract}

\section{INTRODUCTION}

Soffer and his colleagues (Landau, Schwartz \& Soffer, 1960; Soffer, Futterweit \& Salvaneschi, 1961; Soffer, Salvaneschi \& Futterweit, 1962) have demonstrated the presence of a gonadotrophin inhibiting factor in the urine of young children and adult male and female subjects. The assay method for this substance depends on reduction of the uterine weight of the intact immature mouse treated with small dosages of human chorionic gonadotrophin (HCG). Because of the interference which would otherwise be caused by pituitary gonadotrophins in urine, it is necessary to remove these hormones before the assay of the inhibitor and this is accomplished by heating the sample at $100^{\circ} \mathrm{C}$ for $1 \mathrm{hr}$. However, no details have been reported of the hormone inactivation obtained under these conditions or of the specificity of the assay method for the GIF. In the present investigation both these factors were studied, firstly, by assessing the effect of heat on the biological activity of various gonadotrophin preparations and, secondly, by determining the action of either incubated or nonincubated hormone on the assay procedure for the GIF. The results obtained are reported herein. 


\section{Hormones}

\section{MATERIALS AND METHODS}

The following were employed: (1) Ovine pituitary luteinizing hormone (NIH-LH-S3), (2) ovine pituitary follicle-stimulating hormone (NIH-FSH-S1), and (3) human menopausal gonadotrophin (Second international reference preparation for Human Menopausal Gonadotrophin: IRP-HMG).

\section{Incubation of materials}

Incubations were carried out in a boiling water bath for $1 \mathrm{hr}$. The hormones were dissolved in $0.05 \mathrm{M}$-phosphate buffer at $\mathrm{pH} 7.0$ in Quickfit tubes fitted with 'cold-finger stoppers'. Immediately following incubation the materials to be tested were cooled to room temperature and diluted to a suitable concentration before bio-assay; the latter being started within $1 \mathrm{hr}$ of the end of the incubation period.

\section{Bio-assay methods}

These were:

(1) Ovarian ascorbic acid depletion (OAAD) test in rats for LH (Parlow, 1958, 1961). The method was conducted as described by Schmidt-Elmendorff \& Loraine (1962) except that the modification of Bell, Loraine, Mukerji \& Visutakul (1965), in which the material to be tested is injected by the intraperitoneal route, was employed.

(2) Ovarian augmentation test in mice for FsH (Brown, 1955). This technique was performed as described by the originator without major modification.

(3) Inhibition of mouse uterine weight. The procedure described by Soffer et al. (1961) was employed except that each animal received 2.0 i.u. HCG (Pregnyl, Organon), which was administered at the same site as the inhibiting material.

\section{Design of investigation}

Effect of heat on biological activity. A total of sixteen assays was conducted, twelve by the OAAD method and four by the augmentation test. In all of these the results obtained represent a direct comparison of the incubated and nonincubated materials. The assays of NIH-LH were of a symmetrical four-point design while those with NIH-FSH and the Second IRP-HMG were three-point in nature because insufficient material was available to conduct assays at two dose levels after incubation. In none of the four-point assays was lack of parallelism observed between the dose response lines of the incubated and non-incubated hormones (Gaddum, 1953a, b). The total dosage per animal of incubated material was generally 10 to 20 times that of the non-incubated hormone.

Effect of gonadotrophins on the inhibited mouse uterus test. The specificity of the assay method was tested by determining the effect of NIH-LH, NIH-FSH and the Second IRP-HMG on the response of the mouse uterus to $2 \cdot 0$ i.u. HCG. NIH-LH and NIH-FSH were also heated at $100^{\circ} \mathrm{C}$ for $1 \mathrm{hr}$ (see above), and the incubated preparation was administered together with $2 \cdot 0$ i.u. HCG. Only with NIH-LH was it possible to obtain a valid four-point comparison of the inhibition of the 
uterine weight caused by the incubated and non-incubated material. In none of the five assays conducted was lack of parallelism between the dose response curves noted.

TABLE 1

THE EFFECT OF HEAT ON THE BIOLOGICAL ACTIVITY OF

VARIOUS GONADOTROPHINS

\begin{tabular}{l|l|c|c}
\hline \multicolumn{1}{c|}{ Hormone } & Assay method & No. of assays & $\begin{array}{c}\text { Mean } \\
\% \\
\text { destruction }\end{array}$ \\
\hline NIH-LH & OAAD test & 5 & 98 \\
NIH-FSH & OAAD test & 5 & $>90$ \\
Second IRP-HMG & Augmentation test & 2 & 98 \\
& OAAD test & 2 & 93 \\
& Augmentation test & 2 & 95 \\
\hline
\end{tabular}

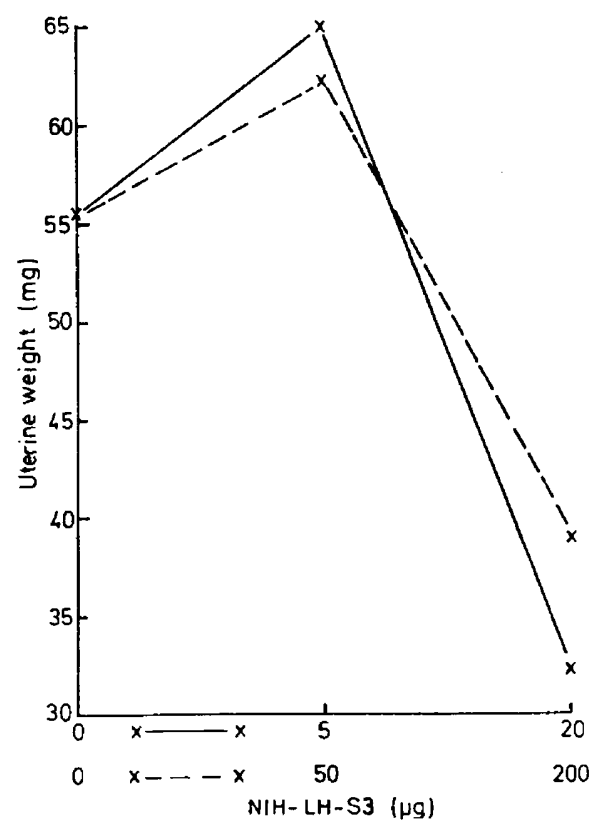

TEXT-Fig. 1. The effect of NiH-LH on the response of the mouse uterus to $2.0 \mathrm{i} . \mathrm{u}$. HCG. , Non-incubated NIH-LH; - - - , incubated NIH-LH.

\section{Effect of heat on biological activity}

\section{RESULTS}

In Table 1 is shown the number of assays conducted with each hormone and the mean percentage loss of biological activity following incubation at $100^{\circ} \mathrm{C}$ for $1 \mathrm{hr}$. It will be seen that, although more than $90 \%$ of each hormone was destroyed, activity could still be detected except in the case of the LH content of NIH-FSH as measured by the OAAD test. With this preparation insufficient material was available to perform assays at a dose level greater than 10 times that of the non-incubated sample. 


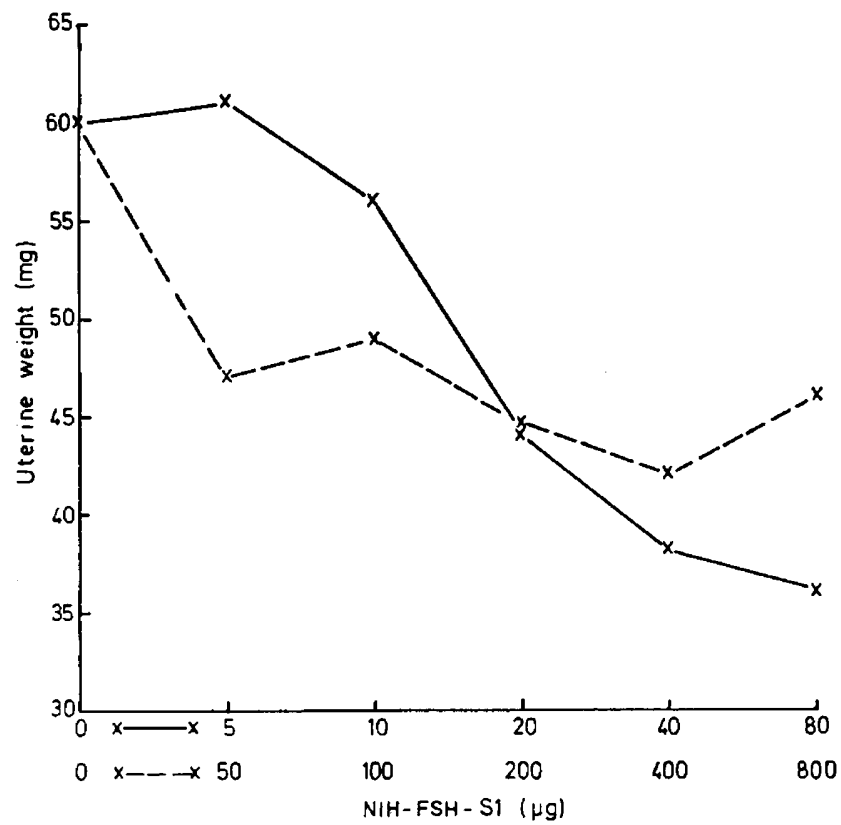

TEXT-FIG. 2. The effect of NIH-FSH on the response of the mouse uterus to $2 \cdot 0 \mathrm{i}$.u. HCG. -, Non-incubated NIH-FSH; -- --, incubated NIH-FSH.

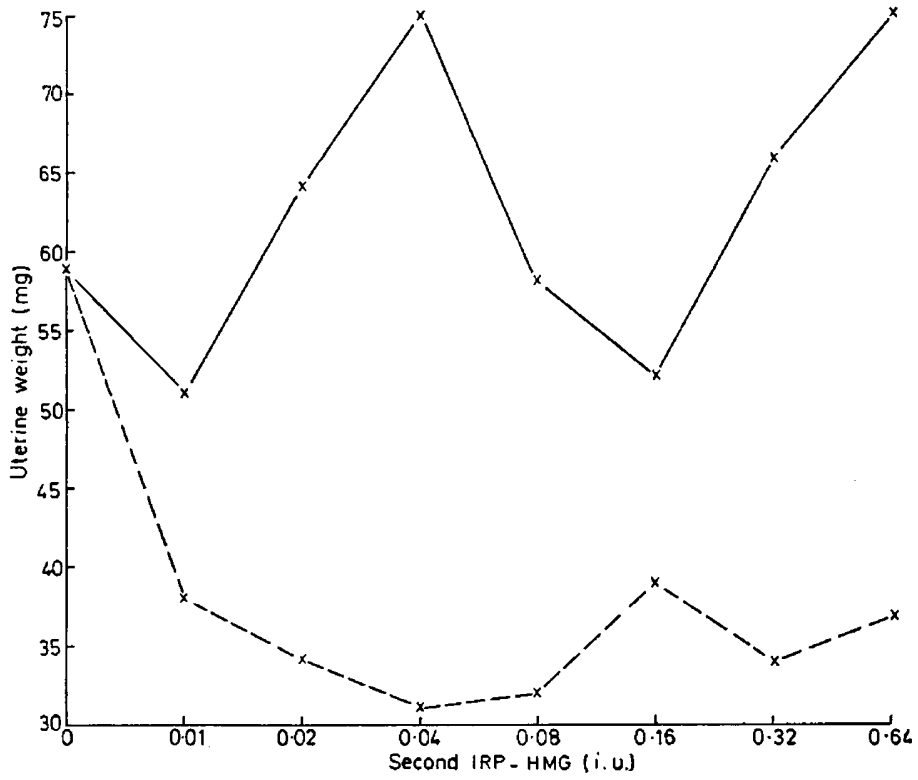

TExT-FIG. 3. The effect of the Second IRP-HMg on the response of the mouse uterus to $2 \cdot 0$ i.u. HGG. $\frac{}{2}$, Second IRP-HMG; - - - , Second IRP-HMG together with $10 \mu \mathrm{g}$ NIH-LH at each dose level. 
The effect of gonadotrophins on the inhibited mouse uterus test

(a) LH. Text-fig. 1 shows the results of a typical experiment in which the effect of incubated and non-incubated NIH-LH on the response of the mouse uterus to $2 \cdot 0$ i.u. HCG was studied. It will be seen that $5 \mu \mathrm{g}$ of non-incubated LH caused a slight increase, while $20 \mu \mathrm{g} \mathrm{LH}$ resulted in a marked decrease in uterine weight. Following incubation, dose levels of 50 and $200 \mu \mathrm{g}$ were required to produce a similar response. The mean destruction of LH by heating as measured by this procedure in a total of five assays was $93 \%$. This figure is similar to that obtained using the OAAD test (see above).

(b) FsH. The results of a typical experiment with NIH-FSH are shown in Textfig. 2. Over the dosage ranges studied both incubated and non-incubated NrH-FSH caused a decrease in the weight of the uterus. However, the slope of the two dose response curves was so flat that it was not possible to make a quantitative assessment of the degree of destruction of NIH-FSH by heat.

(c) Second IRP-Hmg. At the dose levels tested this hormone did not cause a decrease in uterine weight in mice treated with $2 \cdot 0$ i.u. HCG and may have produced an increase at certain dosages (Text-fig. 3 ).

In view of the fact that the Second IRP-HMG contains both FSH and LH activites, it seemed of interest to study the effect of altering the FSH:LH ratio of the preparation by the addition of $\mathrm{LH}$. A dosage of $10 \mu \mathrm{g} \mathrm{NIH-LH}$ was therefore added at each dose level of the Second IRP-HMG tested. As shown in Text-fig. 3, the LH preparation caused a decrease in uterine weight when compared with the response to 2.0 i.u. HCG but the effect was similar at all dosages and it is clear that the Second IRP-HMG did not cause any effect in addition to that produced by NIH-LH.

\section{DISCUSSION}

Borth, Lunenfeld \& Menzi (1961) have shown that when urinary gonadotrophins are heated at 60 to $80^{\circ} \mathrm{C}$ a decrease in their biological activity, as measured by the mouse uterus test and the rat ovarian hyperaemia assay, generally occurs. Occasionally, however, potentiation was noted and Borth et al. (1961) suggested that the variable results obtained may have been due to the differential destruction of the FSH and LH activities of the preparations studied. In the present study, in which specific bio-assay methods for FSH and LH were employed, almost all the biological activity of the various preparations studied was destroyed. However, except in the case of the LH content of NIH-FSH, biological activity could still be detected after incubation. At the present time no explanation can be offered for this finding.

The results reported herein have confirmed the observations of Riley (1961) and Mukerji (1963) that NIH-LH has an inhibitory effect on the stimulated mouse uterus. It has also been shown that NIH-FSH can cause a similar depression and even when allowance is made for the $\mathrm{LH}$ contamination of this material, it is apparent that the decrease in weight of the HCG-treated mouse uterus was due to FSH (see Schmidt-Elmendorff, Loraine \& Bell, 1962). The fact that the Second IRP-HMG exerted no inhibitory effect on the assay method for the GIF may be associated with the dosage of hormone employed. However, although 
the LH activity of 0.64 i.u. of the Second IRP-HMG would be inadequate (Textfig. 1) the Fsh content of this dosage would be sufficient to cause a depression of uterine weight (Text-fig. 2). When the LH : FSH ratio of the Second IRP : HMG was altered by the addition of NIH-LH no effect due to increase in the dosage of the Second IRP-HMG could be detected. In view of the finding that no depression of uterine weight could be obtained with non-incubated material experiments with incubated hormone were not conducted.

The results obtained in the present investigation suggest that the assay method for the GIF as described by Soffer et al. (1961) is not specific. Thus, the procedure used to destroy gonadotrophins in urine has been shown to inactivate the majority but not all of the biological activity of various preparations. In addition, both incubated and non-incubated NIH-LH and NIH-FSH have been demonstrated to inhibit uterine weight increase in the HCG-treated mouse. It is clear that further work on the specificity of the assay method for the GIF should be undertaken, and that caution should be exercised in interpreting the results obtained in clinical situations in which high urinary gonadotrophin levels are likely to be encountered.

\section{REFERENCES}

Bell, E. T., Loraine, J. A., Mukerji, S. \& Visutakul, P. (1965) Further observations on the ovarian ascorbic acid depletion test for luteinizing hormone. F. Endocr. 32, 1.

BoRth, R., Lunenfeld, B. \& MENzi, A. (1961) Effect of heating on potency of human urinary gonadotropin preparations in different methods of bioassay. Human Pituitary Gonadotropins, p. 179. Ed. A. Albert. Thomas, Springfield.

BRown, P. S. (1955) The assay of gonadotrophin from the urine of non-pregnant subjects. F. Endocr. 13, 59.

Gaddum, J. H. (1953a) Bioassays and mathematics. Pharmac. Rev. 5, 87.

Gaddum, J. H. (1953b) Simplified mathematics for bioassays. 7. Pharm. Pharmac. 6, 345.

Landau, B., Schwartz, H. S. \& Soffer, L. J. (1960) Preliminary report. Presence of a gonadotropininhibiting factor in urine of young children. Metabolism, 9, 85.

MukerJi, S. (1963). Some observations on the biological assay of gonadotrophic hormones. Ph.D. thesis. University of Edinburgh.

Parlow, A. F. (1958) A rapid bioassay method for LH and factors stimulating LH secretion. Fedn Proc. Fedn Am. Socs exp. Biol. 17, 402.

PARLOw, A. F. (1961) Bioassay of pituitary luteinizing hormone by depletion of ovarian ascorbic acid. Human Pituitary Gonadotropins, p. 300. Ed. A. Albert. Thomas, Springfield.

RiLEY, G. M. (1961) In Human pituitary gonadotropins, p. 133. Ed. A. Albert. Thomas, Springfield.

Schmidt-ElmendorfF, H. \& Loraine, J. A. (1962) Some observations on the ovarian ascorbic acid depletion method as a test for luteinizing hormone activity. F. Endocr. 23, 413.

Schmidt-ElmendorfF, H., Loraine, J. A. \& Bell, E. T. (1962) Studies on the biological activity of various gonadotrophin preparations. J. Endocr. 24, 349.

Soffer, L. J., Futterweit, W. \& Salvaneschi, J. (1961) A gonadotropin-inhibiting substance in the urine of normal young children. 7. clin. Endocr. Metab. 21, 1267.

Soffer, L. J., Salvaneschi, J. \& Futterweit, W. (1962) A gonadotropin-inhibiting substance in the urine of normal subjects. F. clin. Endocr. Metab. 22, 532. 